\title{
Effect of Experimental Diabetes and Glucagon on cAMP-Dependent Protein Kinase in Rat Liver
}

\author{
H. E. Weber ${ }^{1}$, L. A. Menahan ${ }^{2}$, S. N. Chaudhuri ${ }^{3}$, and J. C. Shipp \\ Department of Internal Medicine, University of Nebraska, College of Medicine, Omaha, Nebraska, USA
}

Summary. Liver protein kinase was determined in the absence and presence of $\mathrm{CAMP}^{4}$. Experimental alloxan diabetes resulted in a decrease in total protein kinase (+ cAMP) and an increase in the activity ratio $\frac{(- \text { cAMP })}{(+ \text { cAMP })}$ in liver. Insulin treatment of diabetic rats reversed the observed changes in protein kinase in liver. Glucagon administered in vivo to normal rats caused an increase in the activity ratio and a decrease in total protein kinase activity in liver. The changes are similar to those in diabetes. A decrease in the ratio of insulin to glucagon in diabetes may account for the changes in protein kinase observed.

Key words: Liver, protein kinase, cyclic AMP, alloxan diabetes, insulin, glucagon,

Recent work has indicated that cyclic AMP was increased approximately two to four fold in the rat heart [1] and liver [1,2] in diabetes. There is general agreement, at least in mammalian systems, that a protein kinase is one of the intermediate steps between hormone activation of adenylate cyclase and the physiological response [3]. Protein kinase has been shown to consist of a regulatory component (R) which binds cAMP and a catalytic (C) subunit which is cAMP independent $[4,5]$.

\footnotetext{
1 Present Address: Department of Medicine, University of California, Los Angeles, California 90024, USA

2 Present Address: Department of Pharmacology, Medical College of Wisconsin, Milwaukee, Wisconsin 53233, USA

3 Present Address: Office of the Dean, Goa Medical College, Panaji (Goa), India

4 Abbreviations used in the text: cAMP, cyclic 3',5'-adenosine monophosphate
}

In 1971, Brostrom [6] proposed the following equation to explain the action of cAMP on protein kinase:

$\mathrm{RC}+\mathrm{cAMP} \rightleftharpoons \mathrm{R} \cdot \mathrm{cAMP}+\mathrm{C}$

Hormones, which have as their "second messenger" cAMP, would be expected to increase or decrease the proportion of protein kinase in the active (C) form. Corbin, Soderling and Park [7] have proposed an activity ratio (the ratio of protein kinase activity in the absence of cAMP to the activity in the presence of the nucleotide) as an expression of $\frac{\mathrm{C}}{\mathrm{RC}+\mathrm{C} \text {. }}$

Although definitive evidence for a role of cAMP-dependent protein kinase in the activation of glycogenolysis and lipolysis [3] has been obtained, increased [CAMP] and the resulting activation of protein kinase, e.g. increased protein activity ratio in the diabetic liver [2], may be responsible for the increased gluconeogenesis and other metabolic disturbances in liver metabolism in diabetes.

Almost ten years ago, Jefferson et al. [2] reported that liver [cAMP] was increased two fold in alloxan diabetes. However, calculation of the protein kinase activity ratio from data reported by Gorin and Rosenblum [8] and Zapf et al. [9] indicated little or no increase in the ratio in diabetic liver. It would be expected that the ratio would increase, based on the increase in liver [cAMP] reported to exist in alloxan-diabetes $[1,2]$. Thus, the purpose of the present investigation was to study the effects of alloxan diabetes on rat liver cAMP protein kinase.

\section{Materials and Methods}

Male, albino Sprague-Dawley rats (Holtzman Company, Madison, Wisconsin) weighing $200-250 \mathrm{~g}$ 
Table 1. Serum glucose and free fatty acid levels of controls, diabetic and diabetic rats on insulin ${ }^{\mathbf{a}}$

\begin{tabular}{|c|c|c|c|}
\hline \multirow[t]{2}{*}{ Group } & \multirow{2}{*}{$\begin{array}{l}\text { No. of } \\
\text { rats }\end{array}$} & \multicolumn{2}{|l|}{ Serum } \\
\hline & & $\begin{array}{l}\text { Glucose } \\
\mathrm{mg} / 100 \mathrm{ml}\end{array}$ & $\begin{array}{l}\text { Free Fatty Acids } \\
\mathrm{mmol} / 1\end{array}$ \\
\hline Control & 3 & $176 \pm 9$ & $0.63 \pm 0.05$ \\
\hline Diabetic & 4 & $740 \pm 124$ & $1.13 \pm 0.13$ \\
\hline Diabetic on Insulin & 4 & $101 \pm 9$ & $0.43 \pm 0.01$ \\
\hline
\end{tabular}

a All groups of diabetic rats received Lente insulin (6 U daily, subcutaneously, s.c.) for seven days or longer. The last injection was made 40 hours prior to the start of the experiment. The diabetic on insulin group of rats obtained $6 \mathrm{U}$ of Lente insulin (s.c.) daily including the day of experiment. Mean \pm standard error is shown

Table 2. Effect of insulin in vivo on liver protein kinase of diabetic rats ${ }^{\mathrm{a}}$

\begin{tabular}{|c|c|c|c|c|}
\hline \multirow[t]{2}{*}{ Group } & \multirow[t]{2}{*}{$\begin{array}{l}\text { No. of } \\
\text { rats }\end{array}$} & \multicolumn{2}{|c|}{$\begin{array}{l}\text { Protein Kinase } \\
\text { (p moles/mg } \\
\text { protein } / \mathrm{min} \text { ) }\end{array}$} & \multirow{2}{*}{$\begin{array}{l}\text { Activity } \\
\text { Ratio } \\
(-c A M P) \\
(+ \text { cAMP })\end{array}$} \\
\hline & & $\begin{array}{l}\text { Without } \\
\text { cAMP }\end{array}$ & $\begin{array}{l}\text { With cAMP } \\
\left(5 \times 10^{-6} \mathrm{M}\right)\end{array}$ & \\
\hline Control & 9 & $11.2 \pm 1.1$ & $31.2 \pm 1.8$ & $0.35 \pm 0.02$ \\
\hline Diabetic & 9 & $8.6 \pm 1.0$ & $15.0 \pm 1.5$ & $0.56 \pm 0.04$ \\
\hline $\begin{array}{l}\text { Diabetic + Insulin } \\
(30-40 \mathrm{~min})\end{array}$ & 11 & $8.8 \pm 0.7$ & $25.8 \pm 2.1$ & $0.34 \pm 0.02$ \\
\hline $\begin{array}{l}\text { Diabetic + Insulin } \\
(120 \mathrm{~min})\end{array}$ & 2 & 13.5 & 25.7 & 0.52 \\
\hline
\end{tabular}

a All groups of diabetic rats received insulin ( $6 \mathrm{U}$ daily, s. c.) for seven days or longer. The last injection was made 40 hours prior to the start of the experiment. $4 \mathrm{U}$ of regular insulin (s.c.) was given diabetic rats which were sacrificed at the times indicated. Mean \pm standard error is shown

were used. Alloxan-monohydrate (Eastman Organic Chemical Company, Rochester, New York) was dissolved in saline shortly before use. Glucagon (crystalline porcine glucagon, lot 258-D30-138-4) was a gift from the Lilly Research Laboratories, Indianapolis, Indiana. Histone (Type II-A from calf thymus, Sigma Chemical Company, St. Louis, Missouri) was used as a substrate in the protein kinase assay.

To produce experimental diabetes, alloxan $(60 \mathrm{mg} / \mathrm{kg})$ was injected into the tail vein of rats anaesthetized with ether; this was followed by $5 \mathrm{ml}$ of saline intraperitoneally. Twenty-four hours after alloxan administration, $4 \mathrm{U}$ Lente insulin were given subcutaneously (s. c.). On all subsequent days, $6 \mathrm{U}$ Lente insulin was injected s. c. All rats were maintained on insulin for at least 10 days. The acute diabetic state was induced by withholding insulin for 40 hours prior to sacrifice.

Serum glucose and free fatty acids of acutely diabetic rats were increased approximately four and two fold, respectively; serum glucose and free fatty acids in diabetics maintained on insulin were similar to, or less than, controls (Table 1). All rats had access to lab chow and water up to sacrifice.

\section{Preparation of Enzyme}

The abdomen of the ether-anaesthetized rat was opened rapidly. Part of the liver was excised and placed in ice-cold saline. A piece of liver was weighed and homogenized in $10 \mathrm{vol}$. of $0.32 \mathrm{M}$ sucrose containing $50 \mathrm{mM}$ Tris $\cdot \mathrm{HCl}, \mathrm{pH} 7.4 ; 5 \mathrm{mM}$ $\mathrm{MgSO}_{4}$; and $5 \mathrm{mM} \mathrm{KCl}$. The homogenate was spun at $12,000 \times \mathrm{g}$ for $10 \mathrm{~min}$ at $4^{\circ} \mathrm{C}$. The supernatant was then diluted $1: 14$ in a $100 \mathrm{mM}$ glycerol-phosphate buffer, $\mathrm{pH} 6.5$ for the protein kinase assay. Protein content was estimated by the Biuret method [10].

\section{Injection of Glucagon}

Under ether anaesthesia, the abdomen was opened and glucagon $(25 \mu \mathrm{g} / \mathrm{kg}$ body weight) dissolved in $1 \mathrm{ml}$ of saline containing $0.003 \mathrm{~N} \mathrm{HCl}$ was injected rapidly into the portal vein. The needle was left in place (to prevent bleeding) until a part of the liver was removed. Control rats received $1 \mathrm{ml}$ of saline containing $0.003 \mathrm{~N} \mathrm{HCl}$.

\section{Protein Kinase Assay}

The enzyme assay used for measuring the cAMPdependent protein kinase was a modification of that described by Gaballah, Popoff and Sooknandan [11]. The reaction mixture of $0.2 \mathrm{ml}$ contained: $100 \mathrm{mM}$ glycerol phosphate buffer, $\mathrm{pH} 6.5 ; 10 \mathrm{mM}$ magnesium acetate; $10 \mathrm{mM} \mathrm{NaF} ; 3 \mathrm{mM}$ EGTA; $2 \mathrm{mM}$ theophylline; $1.2 \mathrm{mg}$ histone; $5 \mu \mathrm{M}$ cAMP (when added); $5 \mu \mathrm{M}\left[{ }^{32} \mathrm{P}\right]-\mathrm{ATP}$ (New England Nuclear, Boston, Massachusetts), containing $0.5-1.5$ $\times 10^{-6} \mathrm{cpm}$; and $10-40 \mu \mathrm{g}$ protein. The reaction was started with addition of the enzyme and carried out in a shaking incubator at $30^{\circ} \mathrm{C}$ for 20 minutes. $\left[{ }^{32} \mathrm{P}\right]$-histone was isolated according to Gaballah and others [11] and counted in a liquid scintillation spectrometer (Unilux II, Nuclear-Chicago Company). Protein kinase activity was expressed as pmoles of ${ }^{32} \mathrm{P}$ incorporated into histone (pmoles/ $\mu \mathrm{g}$ protein/ $\min )$.

\section{Results}

Reaction rate in the assay mixture was linear over the range of 10 to $40 \mu \mathrm{g}$ of supernatant protein $(12,000 \mathrm{~g} \times 10 \mathrm{~min})$. When rate constants were determined with various concentrations of ATP as substrate and the results plotted as a double-reciprocal graph [12], a $\mathrm{Km}$ for ATP was determined to be approximately $2 \times 10^{-5} \mathrm{M}$. cAMP altered $\mathrm{V}_{\max }$ but not the $\mathrm{Km}$ for ATP. With rat liver supernatant, 
$\mathrm{V}_{\max }$, without $\mathrm{cAMP}$, was 16.8 and with cAMP was $38.8 \mathrm{pmoles} / \mathrm{mg}$ protein $/ \mathrm{min}$.

Liver protein kinase of diabetic rats in the $a b-$ sence of added cAMP was less than controls (Table $2, \mathrm{p}<0.001)$. With ATP as substrate, a doublereciprocal plot [12] in the absence of cAMP indicated a similar $\mathrm{Km}$ for ATP $\left(\sim 2 \times 10^{-5} \mathrm{M}\right)$ in controls and diabetics; however, the $V_{\max }$ in liver of diabetics was approximately half that of controls. Similarly, total protein kinase, measured in the presence of cAMP $\left(5 \times 10^{-6} \mathrm{M}\right)$, in livers of diabetic rats was less than $50 \%$ of that of controls. Because of the large decrease in total protein kinase in livers of diabetic rats, the activity ratio $\frac{(- \text { cAMP })}{(+ \text { cAMP })}$ was increased to a value 1.5 times that of the controls.

Diabetic rats were treated with insulin to see if the effects of diabetes on rat liver protein kinase could be reversed. The major effect of insulin treatment (30-40 minutes) was a $75 \%$ increase in total protein kinase activity ( + cAMP) to a value approaching that in control rats (Table 2). As a result of this increase, the activity ratio $\frac{(- \text { cAMP) }}{(+ \text { cAMP })}$ was decreased to a value similar to that of controls. In rats sacrificed $2 \mathrm{~h}$ following $4 \mathrm{U}$ of regular insulin, liver protein kinase activity in the absence of cAMP increased, resulting in an activity ratio similar to that of diabetic rats.

The time course of the action of insulin on protein kinase in diabetic rats was then determined (Table 3). At 30 minutes, the earliest time point investigated, insulin caused a decrease in the activity ratio and this effect was maximal at 45 minutes at which time the ratio was similar to controls. By $2 \mathrm{~h}$ following $4 \mathrm{U}$ regular insulin, the activity ratio approached the untreated diabetic value.

Because of the known interaction of insulin and glucagon on several metabolic processes in liver [13], the effect of glucagon on liver protein kinase of normal and diabetic rats was determined. In normal rats given glucagon, there was a significant increase $(p<0.01)$ in liver protein kinase activity measured in the absence of cAMP and in the activity ratio $\frac{(- \text { cAMP) }}{\text { (+cAMP) }}$ (Table 4). As with experimental diabetes, there was a decrease in total liver protein kinase activity (+cAMP) following glucagon. Since the insulin/glucagon ratio may be decreased in experimental diabetes, it might be anticipated that glucagon would not have demonstrable effects in the diabetic rat. The increased protein kinase activity ratio of diabetic rat liver was not increased further by glucagon under these conditions (Table 5 ).

If the insulin/glucagon ratio is important in the control of rat liver protein kinase, then it should be possible to prevent the effect of glucagon by insulin
Table 3. Effect of insulin in vivo on liver protein kinase activity ratio of diabetic rats ${ }^{\mathrm{a}}$

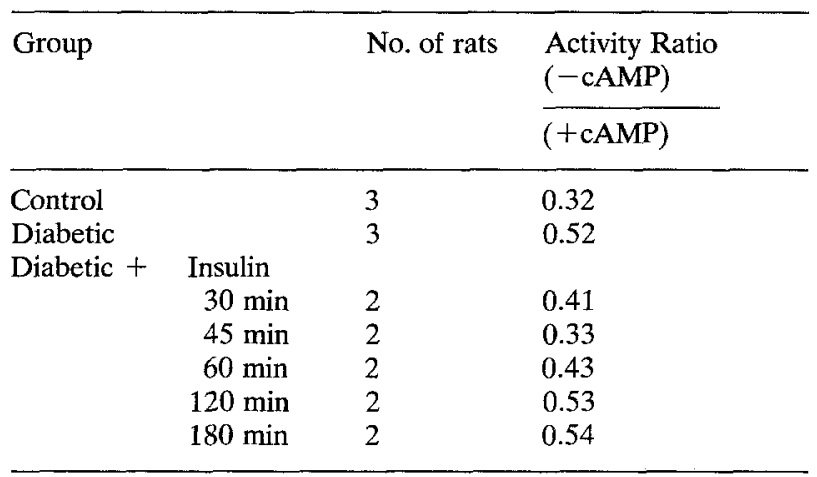

a All groups of diabetic rats received insulin (6 U Lente daily, subcutaneously, for seven days, or longer, and the last injection was 40 hours prior to the start of the experiment. $4 \mathrm{U}$ regular insulin (s. c.) was given to diabetic rats which were sacrificed at the time indicated

Table 4. Effect of glucagon on liver protein kinase of normal rats ${ }^{\mathrm{a}}$

\begin{tabular}{|c|c|c|c|}
\hline \multirow[t]{2}{*}{ Group } & \multicolumn{2}{|c|}{$\begin{array}{l}\text { Protein Kinase } \\
\text { pmoles } / \mathrm{mg} \text { protein } / \mathrm{min}\end{array}$} & \multirow{2}{*}{$\begin{array}{l}\text { Activity Ratio } \\
(- \text { cAMP }) \\
(+c A M P) \\
\left(5 \times 10^{-6} \mathrm{M}\right)\end{array}$} \\
\hline & Without cAMP & With cAMP & \\
\hline Control (6) & $14.0 \pm 1.1$ & $36.1 \pm 1.4$ & $0.39 \pm 0.04$ \\
\hline Glucagon (10) & $18.0 \pm 0.6$ & $30.4 \pm 0.9$ & $0.60 \pm 0.03$ \\
\hline
\end{tabular}

a Glucagon $(25 \mu \mathrm{g} / \mathrm{kg}$ body weight) was injected into the portal vein of ether anaesthetized rats. 30 seconds post injection, the liver was removed and homogenized. Number of rats is shown in parentheses. Mean \pm standard error is shown

Table 5. Effect of glucagon on liver protein kinase of diabetic rats $^{a}$

\begin{tabular}{|c|c|c|c|c|}
\hline \multirow[t]{3}{*}{ Group } & \multirow[t]{3}{*}{ Treatment } & \multicolumn{2}{|c|}{$\begin{array}{l}\text { Protein kinase } \\
\text { (pmoles/mg protein } / \mathrm{min} \text { ) }\end{array}$} & \multirow{2}{*}{$\begin{array}{l}\text { Activity } \\
\text { Ratio } \\
(- \text { cAMP })\end{array}$} \\
\hline & & Without cAMP & With cAMP & \\
\hline & & & $\left(5 \times 10^{-6} \mathrm{M}\right)$ & (+cAMP) \\
\hline & Saline & 10.5 & 23.5 & 0.48 \\
\hline Diabetic & Glucagon & $9.4 \pm 1.1$ & $21.5 \pm 1.8$ & $0.46 \pm 0.07$ \\
\hline Controls & Saline & $14.8 \pm 1.8$ & $39.5 \pm 4.4$ & $0.39 \pm 0.08$ \\
\hline
\end{tabular}

a Glucagon ( $25 \mu \mathrm{g} / \mathrm{kg}$ body weight) was injected into the portal vein of diabetic rats with blood glucose greater than 24 $\mathrm{mM}$. Controls received saline. The liver was removed 30 seconds post injection and homogenized. At least 3 animals were used in each group. Mean \pm standard error is shown

pretreatment. The interactions of insulin and glucagon on the liver protein kinase ratio is best studied with the isolated perfused liver [2].

With this reservation in mind, an in vivo experiment to study such an interaction was carried out. Intraportal glucagon $(25 \mu \mathrm{g} / \mathrm{kg})$ injection resulted in the expected increase in liver protein kinase activity ratio (30 sec after injection) while similar injection of insulin (4 U) caused only a small decrease. How- 
ever, if the same amount of insulin was administered $30 \mathrm{sec}$ prior to glucagon, the action of glucagon was blocked. When insulin was administered $30 \mathrm{sec}$ after glucagon injection, the full increase in the protein kinase ratio following glucagon was observed. The magnitude of the change observed, either complete or no blockage of glucagon action by insulin, was unambiguous. However, this experiment was performed only once since we felt quantitation of this interrelationship including the effects of variables such as time of exposure and amount of both hormones need to be carried out in detail. The isolated perfused rat liver would be the system of choice to obtain such data but it was not available at the time of the study.

\section{Discussion}

The kinetic characteristics of protein kinase from rat liver supernatant were similar to those reported for either the purified enzyme or crude systems from other tissues [3]. These included the Km for ATP $\left(2 \times 10^{-5} \mathrm{M}\right)$ and the fact that cAMP $(5 \mu \mathrm{M})$ affected the $V_{\text {max }}$ without changing the Km for ATP.

The present study showed that experimental diabetes resulted in an increased liver protein kinase activity ratio, a measure of the proportion of protein kinase in the active form (C) and a decrease in the total protein kinase activity measured in the presence of added cAMP. Gorin and Rosenblum [8] and Zapf et al. [9] have reported that total liver protein kinase activity was decreased in alloxan and streptozotocin diabetes. However, these workers found a decrease in the protein kinase activity measured in the absence of cAMP as well as a constant activity ratio. Since cAMP binding was reduced by $30 \%$ in the studies of Gorin and Rosenblum [8] and Zapf et al. [9], one would expect an increase in the proportion of the protein kinase in the $(\mathrm{C})$ form. They suggested that their results could reflect a decrease in de novo synthesis of protein kinase during insulin deficiency. In the present studies, we have shown that the injection of insulin (30-45 minutes before sacrifice) resulted in a return of the liver protein kinase ratio to normal (Tables 2 and 3). Therefore, unless de novo synthesis of protein kinase is extremely rapid, it is unlikely that the results in the present study can be explained by insulin acting by promoting de novo protein kinase synthesis.

The action of injected insulin in the diabetic was of short duration since the activity ratio was returning toward that of the diabetic state within one hour; at two hours, after subcutaneous injection, the activity ratio had returned to that characteristic of the diabetic state (Table 2 and 3 ).

Since glucagon is known to antagonize the action of insulin in liver $[13,14]$, one might expect that glucagon administration to normal rats might mimic the diabetic state. In this study, glucagon, within 30 seconds after intraportal injection, caused an over 1.5 fold increase in the activity ratio to a value similar to that found in diabetes. Total protein kinase activity was decreased within 30 seconds and declined progressively for 6 minutes. Takeda and Ohga [15] reported a doubling of liver protein kinase ratio 5 minutes after the intraperitoneal injection of glucagon. Sudilovsky [16] investigated the effects of glucagon on the liver cAMP system. Similar to findings in the present study, he found a doubling of the activity ratio and a decrease in the in vitro binding of $\left[{ }^{3} \mathrm{H}\right]$ cAMP, which measured the in vivo regulatory unit saturation, one minute after the injection of glucagon. In his studies, total protein kinase also decreased following glucagon.

Thus, what is the significance of the activation of protein kinase by glucagon? Langan $[17,18]$ reported that glucagon injection in the rat caused a 20 fold increase in the phosphorylation of specific serine residue of liver histone $F_{1}$. In extending the findings of Langan $[17,18]$, Takeda and Ohga [15] followed the course of liver protein kinase activation, histone $F_{1}$ phosphorylation and tyrosine aminotransferase induction following glucagon injection. They found that phosphorylation of histone $F_{1}$ preceded the induction of tyrosine aminotransferase and the rate of this phosphorylation was proportional to the intracellular cAMP concentration. This increase in enzyme induction by glucagon may account for the long term increase in gluconeogenesis observed in the diabetic state.

We have found that glucagon at the dose used $(25 \mu \mathrm{g} / \mathrm{kg}$ intraportally) did not cause a further increase in protein kinase activity ratio which was already increased in diabetes. Pilkis, Exton, Johnson and Park [19] reported that low concentrations of glucagon $\left(2 \times 10^{-10} \mathrm{M}\right.$ or less $)$ in the perfusate did not increase cAMP content in the livers of diabetic rats. These workers have attributed this to a decreased responsiveness of adenylate cyclase in liver plasma membranes from diabetic rats.

An interaction between insulin and glucagon in the liver is shown by the present studies. Prior intraportal administration of insulin prevented the resultant increase in the liver protein kinase activity ratio following glucagon. A similar antagonism has been shown to exist in the perfused liver both in relation to cAMP content [14] and the metabolic effects of glucagon, i. e., gluconeogenesis, ketogenesis and ureogenesis [13]. However, the temporal and quantitative relationship between the insulin and glucagon effects on the protein kinase activity ratio must await further studies with a non-recirculating in vitro liver perfusion system.

We observed that total protein kinase activity, 
measured in the presence of added cAMP, was decreased in diabetics and also following glucagon in normals. Similar results following glucagon injection have been reported by Sudilovsky [16]. In tissues examined so far (Walaas et al. [20], Ichii [21] and Korenman and others [22]) with the possible exception of rat fat pads and isolated fat cells (Soderling and others [23]), a decrease in total protein kinase activity in the diabetic state appears to be generalised. Although the exact mechanism for this decrease has not been found, Korenman and others [22] have attributed the decrease following isoproterenol administration, to a translocation of dissociated protein kinase in the microsomal fraction of the uterus. Walaas and others [20] working with the rat diaphragm, have discussed the possibility of inactivation of the released catalytic subunits by the presence of an inhibitor protein.

The importance of the interaction of insulin and glucagon at the level of protein kinase has been indicated in the present study. Furthermore, the insulin/glucagon ratio seems to be important. Unger $[24,25]$ has discussed the significance of a decrease in this ratio in diabetes, a change which may explain some of the metabolic consequences of this disorder. Acknowledgment. We thank Mrs. Peggy Werlhof for skillful technical assistance. The helpful discussion and criticism of Dr. Robert G. Kemp, Department of Biochemistry, Medical College of Wisconsin, Milwaukee, Wisconsin, 53233 are gratefully acknowledged. This work was supported by U.S. Public Health Service Grants Am 13450 and AM 14986 and Eagle's Max Baer Heart Fund.

\section{References}

1. Chaudhuri, S. N., Shipp, J. C.: Cyclic AMP (cAMP) in hearts of alloxan diabetic rats. In: N.S. Dhalla (ed.): Recent advances in studies on cardiac structure and metabolism, Vol. 3, pp. 179-204. Baltimore: University Park Press 1973

2. Jefferson, L.S., Exton, J.H., Butcher, R.W., Sutherland, E.W., Park, C. R.: Role of adenosine $3^{\prime}, 5^{\prime}$-monophosphate in the effects of insulin and anti-insulin serum on liver metabolism. J. Biol. Chem. 243, 1031-1038 (1969)

3. Langan, T. A.: Protein kinases and protein kinase substrates. In: P. Greengard and G. A. Robinson (eds.): Advances in cyclic nucleotide research, Vol. 3, pp. 99-153. New York: Raven Press 1973

4. Brostrom, M.A., Reimann, E.M., Walsh, D.A., Krebs, E. G.: A cyclic $3^{\prime}, 5^{\prime}$-AMP stimulated protein kinase from cardiac muscle. In: G. Weber (ed.): Advances in enzyme regulation, Vol. 8, pp. 191-203. New York: Pergamon Press 1970

5. Gill, G. N., Garren, L. D.: A cyclic $3^{\prime}, 5^{\prime}$-adenosine monophosphate dependent protein kinase from the adrenal cortex: comparison with a cyclic AMP binding protein. Biochem. Biophys. Res. Commun. 39, 335-343 (1970)

6. Brostrom, C.O., Corbin, J.D., King, C. A., Krebs, E. G.: Interaction of the subunits of adenosine $3^{\prime}, 5^{\prime}$-cyclic monophosphate-dependent protein kinase of muscle. Proc. Natl. Acad. Sci. USA 68, 2444-2447 (1971)

7. Corbin, J.D., Soderling, T.R., Park, C.R.: Regulation of adenosine $3^{\prime}, 5^{\prime}$-monophosphate-dependent protein kinase. Preliminary characterization of the adipose tissue enzyme in crude extracts. J. Biol. Chem. 248, 1813-1821 (1973)
8. Gorin E., Rosenblum, S.: Effect of triamcinolone treatment, starvation, and diabetes on rat liver protein kinase activity. Biochim. Biophys. Acta 343, 510-519 (1974)

9. Zapf, J., Waldvogel, M., Froesch, E. R.: Protein kinase and cAMP-binding activities in liver and adipose tissue of normal, streptozotocin-diabetic and adrenalectomized rats. FEBS Lett. 36, 253-256 (1973)

10. Hussain, Q.Z., Shah, N.S., Chaudhuri, S. N.: Estimation of serum or plasma protein using qualitative Benedict reagent. Clin. Chim. Acta 6, 447-448 (1961)

11. Gaballah, S., Popoff, C., Sooknandan, G.: Changes in cyclic 3',5'adenosine monophosphate-dependent protein kinase levels in brain development. Brain Res. 31, 229-232 (1971)

12. Lineweaver, H., Burk, J.: The determination of enzyme dissociation constants. J. Am. Chem. Soc. 56, 658-666 (1934)

13. Menahan, L. A., Wieland, O.: Interaction of glucagon and insulin on the metabolism of perfused liver from fasted rats. Eur. J. Biochem. 9, 55-62 (1969)

14. Exton, J.H., Lewis, S. B., Ho, R. J., Park, C. R.: The role of cyclic AMP in the control of hepatic glucose production by glucagon and insulin. In: P. Greengard, O. Paoletti, G. A. Robinson (eds.): Advances in cyclic nucleotide research, Vol. 1, pp. 91-102. New York: Raven Press 1972

15. Takeda, M., Ohga, Y.: Adenosine 3', $5^{\prime}$-monophosphate and histone phosphorylation during enzyme induction by glucagon in rat liver. J. Biochem. (Tokyo) 73, 621-629 (1973)

16. Sudilovsky, O.: In vivo regulation of hepatic protein kinase by adenosine $3^{\prime}, 5^{\prime}$-monophosphate mediated glucose stimulation. Biochem. Biophys. Res. Commun. 58, 85-91 (1974)

17. Langan, T. A.: Phosphorylation of liver histone following the administration of glucagon and insulin. Proc. Natl. Acad. Sci. USA 64, 1276-1283 (1969)

18. Langan, T. A.: Action of adenosine $3^{\prime}, 5^{\prime}$-monophosphate dependent histone kinase in vivo. J. Biol. Chem. 244, 5763-5765 (1969)

19. Pilkis, S. J., Exton, J. H., Johnson, R. A., Park, C. R.: Effects of glucagon on cyclic AMP and carbohydrate metabolism in livers from diabetic rats. Biochim. Biophys. Acta 343, 250-267 (1974)

20. Walaas, O., Walaas, E., Grønnerød, O.: Hormonal regulation of cyclic AMP-dependent protein kinase of rat diaphragm by epinephrine and insulin. Eur. J. Biochem. 40, 465-477 (1973)

21. Ichii, S.: Adenosine $3^{\prime}, 5^{\prime}$-monophosphate, adenosine 3',5'-monophosphate-binding protein kinase in rat adrenal glands: effect of adrenocorticotrophin. Endocrinol. Jpn. 19, 229-235 (1972)

22. Korenman, S. G., Bhalla, R., Sanborn, B. M., Stevens, R. H.: Protein kinase translocation as an early event in the hormonal control of uterine contraction. Science 183, 430-432 (1974)

23. Soderling, T.R., Corbin, J.D., Park, C. R.: Regulation of adenosine $3^{\prime}, 5^{\prime}$-monophosphate-dependent protein kinase. II. Hormonal regulation of the adipose tissue enzyme. J. Biol. Chem. 248, 1822-1829 (1973)

24. Unger, R.H.: Glucagon physiology and pathophysiology. N. Engl. J. Med. 285, 443-445 (1971)

25. Unger, R.H., Faloona, G. R.: The role of pancreatic glucagon, in health and diabetes mellitus. In: R. Rodriquez, J. Vallence-Owen (eds.): Diabetes, Proceedings of the Seventh Congress of the International Diabetes Federation, pp. 601-609. Princeton: Excerpta Medica 1971

Received: August 31, 1976, and in revised form: January 6, 1977

Joseph C. Shipp, M.D.

Professor and Chairman

Department of Internal Medicine

University of Nebraska College of Medicine

Omaha, NE 68105, USA 